\section{Australian Journal of \\ Crop Science}

AJCS 14(04):667-674 (2020)

doi: 10.21475/ajcs.20.14.04.p2310

\section{In vitro fungitoxic potential of Lippia gracilis (Schauer) essential oil against} phytopathogens

\section{Kevison Romulo da Silva França ${ }^{1 *}$, Flavia Mota de Figueredo Alves ${ }^{1}$, Tiago Silva Lima ${ }^{1}$, Alda Leaby dos Santos Xavier ${ }^{1}$, Plínio Tércio Medeiros de Azevedo ${ }^{1}$, lonaly Gomes de Araújo ${ }^{1}$, Lídia Pinheiro da Nóbrega ${ }^{1}$, Yaroslávia Ferreira Paiva ${ }^{2}$, Hailton da Silva Barboza ${ }^{3}$, Antônio Francisco de Mendonça Júnior ${ }^{4}$, Ana Paula Medeiros dos Santos Rodrigues ${ }^{5}$ and Tiago Augusto Lima Cardoso ${ }^{6}$}

\author{
${ }^{1}$ Agroindustrial Systems, Federal University of Campina Grande, Pombal, PB, Brazil \\ ${ }^{2}$ Process Engineering, Federal University of Campina Grande, Campina Grande, PB, Brazil \\ ${ }^{3}$ Rural Federal University of Semiarid, Mossoró, RN, Brazil \\ ${ }^{4}$ Agronomy Department, Rural Federal University of Pernambuco, Recife, PE, Brazil \\ ${ }^{5}$ Agronomy/Plant Protection, Rural Federal University of Semiarid, Mossoró, RN, Brazil \\ ${ }^{6}$ Phytopathology Laboratory, Federal University of Campina Grande, Pombal, PB, Brazil
}

\title{
*Corresponding author: kevsfranca@gmail.com
}

\section{Abstract}

This study evaluates the in vitro effects of Lippia gracilis essential oil on the mycelial growth of phytopathogenic fungi. Experiments were carried out using a completely randomized design to assess the effects of eight treatments. Five replicates were evaluated for each experimental group. The essential oil was incorporated into the potato dextrose culture medium and poured into Petri dishes. Treatments were comprised of different concentrations of the oil $(0.0125,0.025,0.05,0.1$, and $0.2 \%)$, a negative control $(0.0 \%)$, and two positive controls (commercial fungicides). The plates were inoculated with fungi including Colletotrichum gloeosporioides, $C$. musae, C. fructicola, C. asianum, Alternaria alternata, A. brassicicola, Fusarium solani, F. oxysporum f. sp. cubense, and Lasiodiplodia theobromae and were incubated for seven days at $27 \pm 2^{\circ} \mathrm{C}$. The following variables were measured to verify the differences observed among treatments: percentage of mycelial growth inhibition and index of mycelial growth speed. All concentrations of $L$. gracilis oil inhibited the mycelial growth of the fungal species evaluated. The complete inhibition was observed between concentrations of 0.0125 and $0.1 \%$. Treatment with oil inhibited fungal growth with similar, or even greater, efficiency than commercial fungicides.. We recommend the development of in vivo tests to verify whether $L$. gracilis essential oil can protect against fungal disease in live plants.

Keywords: Alternaria spp., alternative control, Colletotrichum spp., Fusarium spp., Lasiodiplodia sp., phytopathogenic fungi, fungitoxicity.

Abbreviations: ${ }^{\circ} \mathrm{C} \_$degrees Celsius; $\mathrm{cm}$ day ${ }^{-1}$ _centimeters per day; $\mathrm{df}_{-}$degrees of freedom; $\mathrm{g} \mathrm{L}^{-1}$ grams per liter; EO_Essential oil; IMGS_Index of mycelial growth speed; MICest_Minimum estimated concentration; MIC_Minimum inhibitory concentration; $\mathrm{mL} \mathrm{L}^{-}$ ${ }_{1}$ _mililiter per liter; PGI_Percentage of mycelial growth inhibition; ppm_part per million; SD_standard deviation; $\mu L^{-1} L^{-1}$ microliter per liter; $\mu \mathrm{L} \mathrm{mL}^{-1} \_$microliter per milliliter.

\section{Introduction}

Agricultural production faces several phytosanitary problems worldwide, which negatively affect productivity and the quality of agricultural products. For example, diseases caused by phytopathogenic fungi result in production losses of a wide variety of crops and, subsequently, result in economic losses (Brum et al., 2014).

Fungal genera including Colletotrichum, Alternaria, Fusarium, and Lasiodiplodia are comprised of species capable of causing disease in a wide variety of economically important crops. Among these, we highlight the stem bleeding and gummosis, which are primary diseases of cashew trees (Anacardium occidentale L.), caused by L. theobromae
(Muniz et al., 2011); Panama disease, which is a significant disease of banana (Musa sp.), caused by $F$. oxysporum f. sp. cubense (Castro et al., 2008); soybean (Glycine max L.) common bean (Phaseolus vulgaris L.), and cassava (Manihot esculenta Cranz.) root rot, caused by $F$. solani (Poltronieri et al., 2002; Aoki et al., 2003, Teixeira et al., 2012); anthracnose of papaya (Carica papaya L.), mango (Mangifera indica L.), and banana, caused by Colletotrichum spp. (Bonnet et al., 2013; Ribeiro et al., 2016; Shivas et al., 2016); the rot, which occurs in papaya and muskmelon (Cucumis melo L.), is caused by A. alternata (Nascimento et al., 2014; Barboza, 2015); and diseases of Brassica species caused by $A$. 
brassicicola (Deep and Sharma, 2012).

The conventional treatment of fungal diseases involves the use of chemical pesticides that, due to their high toxicity, contaminate the environment (Candido e Silva and Melo, 2013), affect human health, and raise agricultural production costs (Perina, 2014). In addition, they limit the export of agricultural products, as a result of the restrictive norms of several countries with regard to the use and residues of chemicals for growing food (Adami et al., 2016).

To reduce hazards posed by use of agrochemicals, alternative products have been developed that are designed to reduce the use of conventional synthetic pesticides. An alternative product should effectively control phytopathogens, have a low cost, not produce environmental or human health risks. Among products widely tested for this purpose, the essential oils extracted of aromatic plants, whose antifungal activity has been previously reported in several studies (Carnelossi et al., 2009; Santos et al., 2010; Oliveira Júnior et al., 2013; Santos et al., 2014; Peixinho, Ribeiro and Amorim, 2017), are of particular interest.

Studies evaluating the essential oil (EO) of Lippia gracilis (Schauer) demonstrated that it possessed a diversity array of biological activities, which included antimicrobial effects. Chemical analysis of $L$. gracilis EO revealed that thymol and/or carvacrol were its primary components (Matos et al., 1999; Silva et al., 2008; Ferraz et al., 2013; Bitu et al., 2014; Franco et al., 2014), which have been shown to possess antimicrobial properties (Albuquerque et al., 2006; Kordali et al., 2008; Morcia et al., 2012; Abbaszadeh et al., 2014). In the control of phytopathogens, this EO inhibits the development of Macrophomina phaseolina (Ugulino et al., 2018Alternaria sp. (Barboza, 2015), and Rhizoctonia solani (Silva et al., 2012).

The use of $L$. gracilis EO against phytopathogens has several advantages over conventionally used, synthetic pesticides, for example, it rapidly degrades in the environment ( $\mathrm{Hu}$ and Coats, 2008) and has a low degree of toxicity (Guilhon et al., 2011). This work aims to evaluate the in vitro effects of $L$. gracilis EO on the mycelial growth of a set of phytopathogenic fungi. Our results will inform agricultural practices aiming to promote use of EOs to enhance the management of phytopathogens, reducing negative impacts associated with the exclusive use of chemical pesticides.

\section{Results and Discussion}

\section{Mycelial growth inhibition and growth rate}

The $L$. gracilis EO reduced the mycelial growth and overall growth rates of all phytopathogens considered at all EO concentrations assessed (Figure 1). The percentage of inhibition increased significantly as EO concentration increased until maximum inhibitory values were reached (PGI = 100\%; Figure 2).

The total inhibition of C. gloeosporioides, C. musae, A. alternata, A. brassicicola, F. solani, and F. oxysporum f. sp. cubense occurred at EO concentrations of $0.025 \%$ and greater. Further, growth of $C$. fructicola and L. theobromae was completely inhibited with $0.1 \%$ EO. All tested concentrations were capable of complete growth inhibition of $C$. asianum. The concentrations referred to here are the lowest concentrations capable of inhibiting $100 \%$ of the growth each organism tested and will subsequently be referred to as minimum inhibitory concentrations (MICs;
Table 1).

Equations generated by regressions using the quadraticplateau model allowed the calculation of minimum estimated concentrations (MICest), which were slightly different from MIC (Table 1). The estimations suggested that the mycelial growth of $C$. gloeosporioides, C. musae, $C$. fructicola, F. solani, and L. theobromae could be inhibited entirely at lower concentrations than the observed. Growth rate indices decreased as EO concentrations increased until the growth of phytopathogens was completely inhibited at their respective MICs (see table 1 ). These rates significantly differed from negative controls, which had the fastest rates of growth (Table 2).

Percentages of mycelial growth inhibition (PGIs) and mycelial growth rate indices (IMGS) differed significantly between the nine fungal species and six concentrations of the EO evaluated (Table 3). Also, sources of variation interacted significantly, as each fungal species reacted differently to increases in the concentrations of EOs. In all cases, dosedependent behavior was observed, that is, inhibition increased as concentration increased. However, minimum inhibitory concentrations varied among species. This result suggests that the fungal species have different susceptibility profiles to $L$. gracilis EO, which may be a result of differences among the defense mechanisms employed by the species tested.

Our results demonstrate the powerful antifungal effect of $L$. gracilis EO, which inhibited the growth of evaluated fungi even in low concentrations. Although mechanism details of L. gracilis EO-mediated growth inhibition are poorly understood, it is believed that these compounds dissolve fungal membranes and cell walls by altering cell permeability, which promotes the loss of essential macromolecules (Isman and Machial, 2006; Pina-Vaz et al., 2004; Segvić Klarić et al., 2007). The fungicidal activity of thymol and carvacrol involves inhibition of ergosterol biosynthesis and causes severe damage to cell membranes, an action that leads to cell death (Ahmad et al., 2011).

Also, using $L$. gracilis EO at concentrations close to or greater than those evaluated in this work, other authors have obtained similar results. For example, under in vitro conditions, Ugulino et al. (2018) achieved total inhibition of Macrophomina phaseolina growth at all tested concentrations (0.4 to $1.0 \%$ ). Further, when evaluating the growth of Alternaria sp.Barboza (2015) showed that growth of the species was completely inhibited when given a dose of $750 \mu \mathrm{L} \mathrm{L}{ }^{-1}$ EO (0.075\%). Albuquerque et al. (2006) reported the total inhibition of Curvularia lunata growth when $440 \mu \mathrm{L}$ $\mathrm{L}^{-1}(0.044 \%)$ EO was provided.

Other species of the genus Lippia have the same fungitoxic potential as $L$. gracilis in the control of phytopathogens. Souza Júnior et al. (2009) assessed the effect of L. sidoides and $L$. citriodora EOs against $C$. gloeosporioides and obtained complete inhibition of fungal growth at all tested concentrations, which ranged from 1 to $10 \mu \mathrm{L} \mathrm{mL}^{-1}(0.1$ to 1.0\%). In the control of $L$. theobromae, Mota et al. (2002) reported that the in vitro effect of $L$. sidoides EO was the total inhibition of fungal growth at all concentrations tested, which ranged from 0.05 to $1.0 \%$. The EOs obtained from different species of the genus Lippia have been shown to have similar chemical compositions, with only small variations only in the proportion of their components (Cruz et al., 2013). This compositional similarity may explain similarities reported with respect to the capacities of 
Table 1. Minimum inhibitory concentrations of Lippia gracilis essential oil against a set of phytopathogens.

\begin{tabular}{lcc}
\hline Phytopathogens & MIC* (\%) & MICest** (\%) \\
\hline Colletotrichum gloeosporioides & 0.025 & 0.023 \\
Colletotrichum musae & 0.025 & 0.023 \\
Colletotrichum fructicola & 0.1 & 0.048 \\
Colletotrichum asianum & 0.0125 & 0.041 \\
Alternaria alternata & 0.025 & 0.042 \\
Alternaria brassicicola & 0.025 & 0.029 \\
Fusarium oxysporum f. sp. cubense & 0.025 & 0.030 \\
Fusarium solani & 0.025 & 0.022 \\
Lasiodiplodia theobromae & 0.1 & 0.034 \\
\hline
\end{tabular}

${ }^{*}$ Minimum inhibitory concentration observed on in vitro test; ${ }^{* *}$ Minimum inhibitory concentration estimated by the regression analysis using quadratic-plateau model.

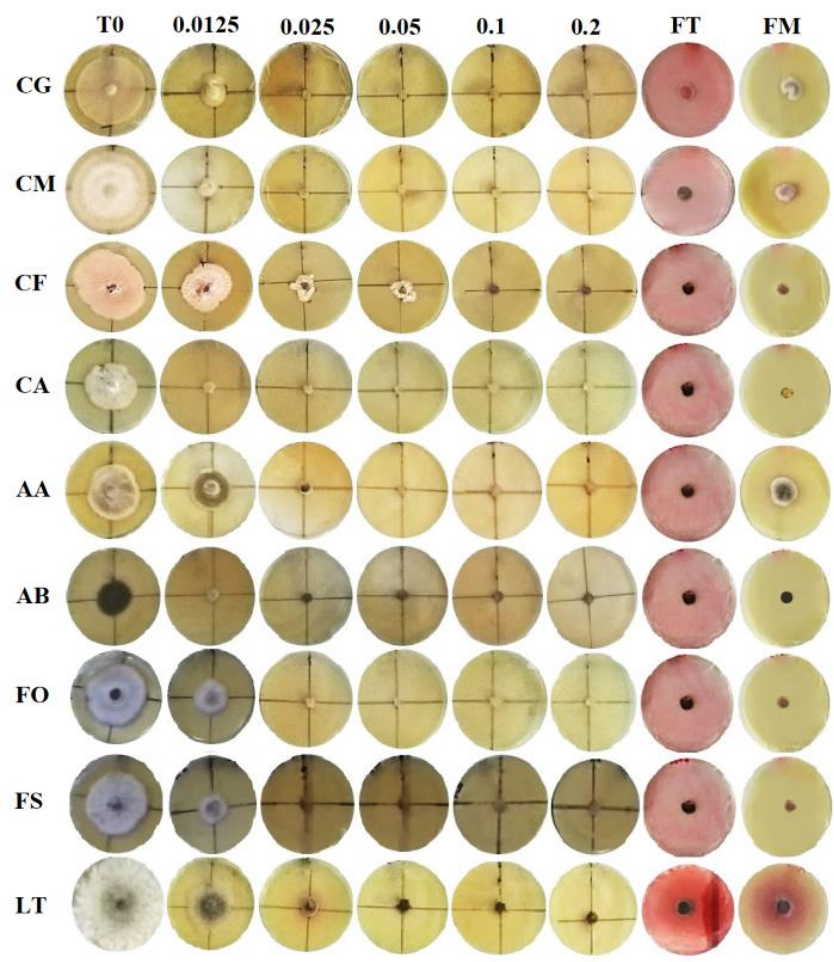

Fig 1. Comparison of the mycelial growth of phytopathogens post-exposure to treatment with Lippia gracilis essential oil and controls. The negative control treatment is indicated by TO, FT and FM indicate positive controls ( $1 \mathrm{ml} \mathrm{L}^{-1}$ of Thiram and $0.2 \mathrm{~g} \mathrm{~L}^{-1}$ of Mancozeb, respectively); 0.0125 to $0.2 \%$ are $L$. gracilis essential oil concentrations (\%), CG indicates Colletotrichum gloeosporioides, $\mathrm{CM}$ indicates Colletotrichum musae, CF indicates Colletotrichum fructicola, CA indicates Colletotrichum asianum, AA indicates Alternaria alternata, $\mathrm{AB}$ indicates Alternaria brassicicola, FS indicates Fusarium solani, FO indicates Fusarium oxysporum $\mathrm{f}$. $\mathrm{sp}$. cubense and LT indicates Lasiodiplodia theobromae.

Table 2. Index of mycelial growth speed $\left(\mathrm{cm}\right.$ day $^{-1} \pm \mathrm{SD}$ ) values of phytopathogenic fungi after treatment with minimum concentrations of Lippia gracilis essential oil and the control treatments.

\begin{tabular}{|c|c|c|c|c|}
\hline Phytopathogen & Negative control & MIC* & Tiram & Mancozeb \\
\hline Colletotrichum gloeosporioides & $0.88 \pm 0.01 a^{* *}$ & $\mathrm{NG} * * * \mathrm{~b}$ & NG b & NG $b$ \\
\hline Colletotrichum musae & $1.50 \pm 0.07 a$ & NG b & NG $b$ & $0.08 \pm 0.08 b$ \\
\hline Colletotrichum fructicola & $0.82 \pm 0.23 a$ & NG b & NG b & $N G \mathrm{~b}$ \\
\hline Colletotrichum asianum & $0.50 \pm 0.05 a$ & NG b & NG b & NG b \\
\hline Alternaria alternata & $0.58 \pm 0.04 \mathrm{a}$ & NG b & NG b & $0.13 \pm 0.11 b$ \\
\hline Alternaria brassicicola & $0.33 \pm 0.01 \mathrm{a}$ & NG C & NG c & $0.11 \pm 0.02 b$ \\
\hline Fusarium solani & $0.89 \pm 0.08 a$ & NG C & $0.02 \pm 0.02 c$ & $0.24 \pm 0.02 b$ \\
\hline Fusarium oxysporum f. sp. cubense & $0.81 \pm 0.02 \mathrm{a}$ & NG c & $0.06 \pm 0.02 b$ & NG c \\
\hline Lasiodiplodia theobromae & $2.56 \pm 0.08 \mathrm{a}$ & NG b & NG b & NG b \\
\hline
\end{tabular}



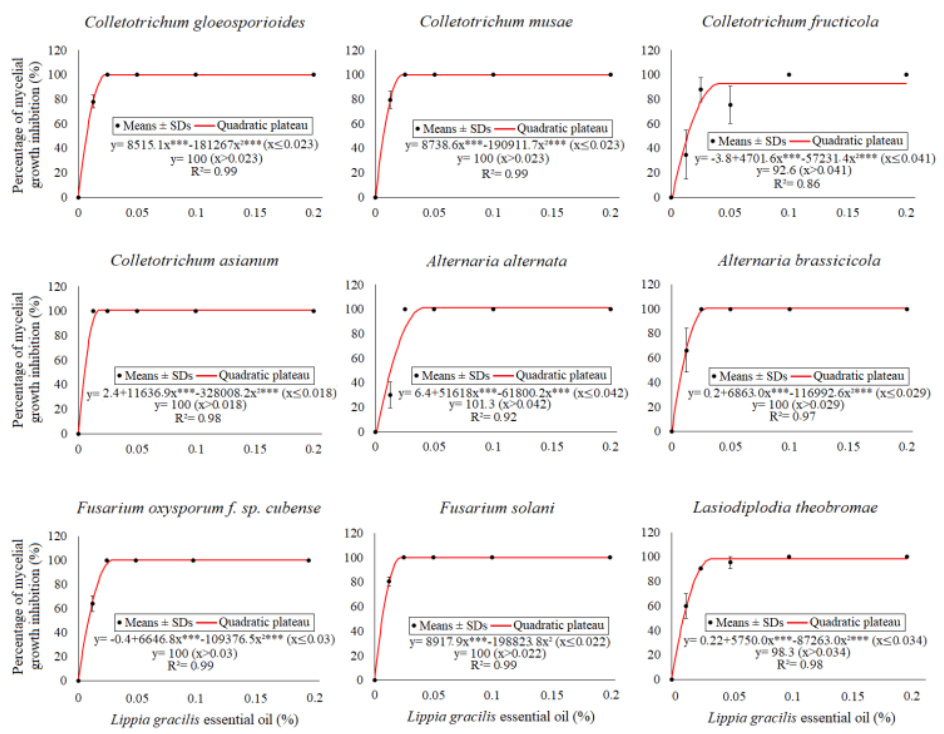

Fig 2. Effect of different concentrations of Lippia gracilis essential oil on the mycelial growth of phytopathogens. The red line shows the direction of effect estimated by a quadratic plateau regression. ${ }^{* * *} \mathrm{P}<0.001$.

Table 3. Analysis of variance associated with the observed percentage of mycelial growth inhibition (PGI) and index of mycelial growth speed (IMGS) among eight treatments of nine fungal species.

\begin{tabular}{lccccc}
\hline Percentage of mycelial growth inhibition (PGI) & \multicolumn{7}{c}{} \\
\hline Sources of variation & Sum of sqrs & Df & Mean square & F-value & P-value \\
Fungal species & 5592.6 & 8 & 699.08 & 7.1956 & 0.0001 \\
Treatments & $3.82 \mathrm{E}+05$ & 15 & 25444 & 261.89 & 0.0001 \\
Interaction & 12486 & 120 & 104.05 & 1.071 & 0.0001 \\
Residual & 20985 & 216 & 97.153 & & \\
Total & $4.21 \mathrm{E}+05$ & 359 & & & \\
\hline Index of mycelial growth speed (IMGS) & & & & & \\
\hline Sources of variation & Sum of sqrs & Df & Mean square & F-value & P-value \\
Fungal species & 5.3324 & 8 & 0.66655 & 51.643 & 0.0001 \\
Treatments & 36.269 & 15 & 2.4846 & 192.5 & 0.0001 \\
Interaction & 15.487 & 120 & 0.12906 & 9.9989 & 0.0001 \\
Residual & 2.7879 & 216 & 0.012907 & & \\
Total & 60.876 & 359 & & &
\end{tabular}
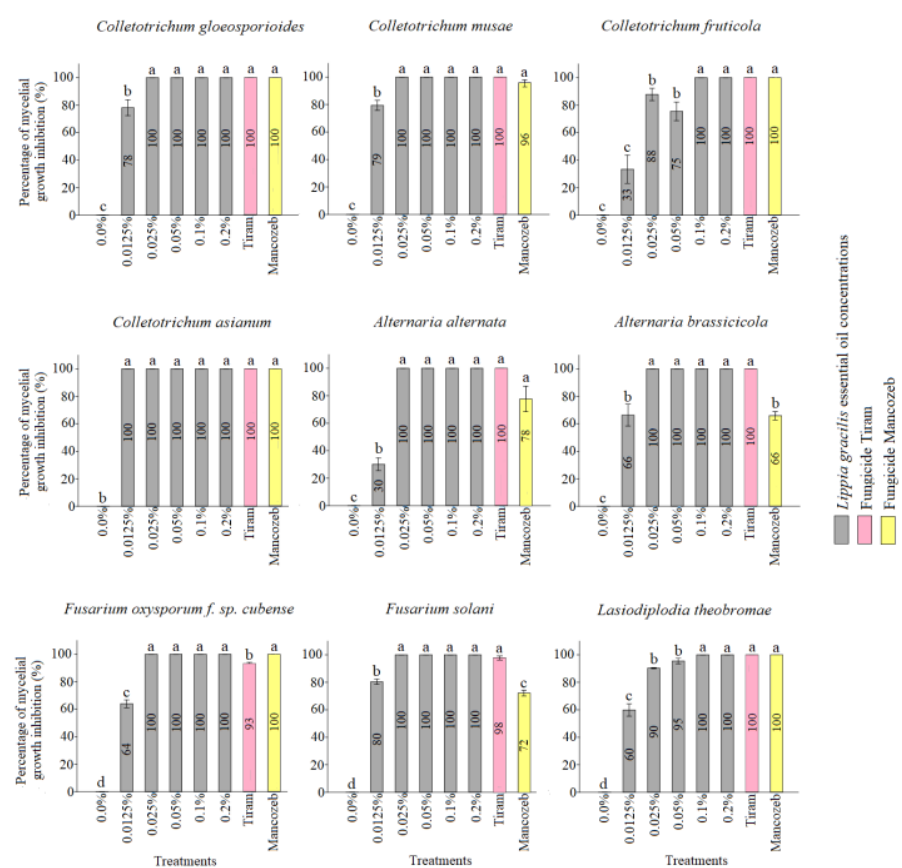

Fig 3. Inhibition of the mycelial growth of phytopathogens after they were treated with different concentrations of Lippia gracilis 
essential oil and controls.

inhibit fungal growth. Many EOs extracted from other plant species have shown either similar, or inferior effects against the fungal species assessed. For example, the EO of Brazilian Peppertree (Schinus terebinthifolius) inhibited only $79 \%$ of the mycelial growth of $C$. gloeosporioides at a concentration of $0.5 \%$ (Oliveira Júnior et al., 2013). Further lemongrass EO (Cymbopogon citratus) at concentrations ranging from 0.15 to $1.25 \mu \mathrm{L} \mathrm{mL}^{-1}(0.015$ to $0.125 \%)$ inhibited only 37.8 and $37 \%$ of the mycelial growth of $C$. fructicola and C. asianum, respectively (Oliveira et al., 2018).

The Mexican-tea EO (Chenopodium ambrosioides) completely inhibited the growth of $C$. gloeosporioides, $C$. musae, and F. oxysporum at $0.3 \%$ (Jardim et al., 2010). Lower concentrations resulted in the moderate inhibition of growth, which varied between 40 and 50\%. Peppermint EO (Mentha piperita) completely inhibited the growth of the aforementioned fungi at a concentration of $0.2 \%$ or greater (Freire et al., 2012). Lemongrass EO completely inhibited $F$. solani at doses of 500, 1,000 and 1,500 ppm $(0.05,0.1$, and $0.15 \%$, respectively) (Mishra and Dubey, 1994). A concentration of $2 \%$ frankincense EO (Acacia farnesiana) inhibited $A$. brassicicola growth $71.29 \%$, while a $1.0 \%$ concentration of acacia oil (Boswellia carterii) resulted in the complete inhibition of the species (Udomsilp et al., 2009). On the other hand, the inhibitory effects of peppermint EO on $A$. alternata growth ranged from 37.1 to $41.6 \%$ when $1.0 \%$ EO was assessed. Through the regression analysis, the estimated maximum concentration for total inhibition of growth was calculated to occur at a concentration of $2.26 \%$ EO (França et al., 2018).

Each EO tested was determined to possess antimicrobial activity against a range of microorganisms. However, the concentrations required to obtain significant effects vary depending on the pathogen subjected to treatment. Also, antifungal efficiency depends the susceptibility of the microbe assessed and the chemical composition of the EO, which varies between plant species (Antunes and Cavaco, 2010).

\section{Comparison of $L$. gracilis $E O$ and fungicides}

We compared the fungitoxic effects of the EO and two synthetic fungicides (Tiram and Mancozeb) aiming to determine possible antifungal applications of $L$. gracilis EO with respect to their use combatting phytopathogens. Outcomes when using the EO were generally equal to or improved relative to treatment using the fungicides tested (Figure 3). Percentage of inhibition of the mycelial growth rates of C. gloeosporioides, C. musae, C. fructicola, C. asianum, $A$. alternata, and $L$. theobromae using the MIC of the EO were similar to the rates obtained with the commercial fungicides. In the cases of $A$. brassicicola and $F$. solani, the effects were superior to the fungicide Mancozeb and identical to the Tiram. Conversely, F. oxysporum f. sp. cubense, use of the EO produced results that were superior to Tiram and similar to Mancozeb. The similarity and even superiority of $L$. gracilis EO compared to commercial fungicides suggests that, under in vitro conditions, the EO could functionally completely replace the use of either of the products tested.

Due to their high degree of chemical complexity, EOs promote microbial control through synergistic and antagonistic effects that occur between several of their components (Bagamboula et al., 2004; Russo et al., 2013). This complexity produces multiple inhibitory mechanisms that act on several targets simultaneously (Abdel-Kader et al., 2011; Hoyos et al., 2012). Synthetic agrochemicals, on the other hand, may have a single target and mechanism of action (Bebber and Gurr, 2015). The multiple pathways used to combat fungal growth provide EOs a key advantage over synthetic fungicides, because their complexity protects against the acquisition of microbial resistance (Feng and Zheng, 2007).

In the present study, growth of most fungal species tested was paralyzed at concentrations ranging from 0.025 and $0.1 \%$, and some inhibitory concentrations were obtained at significantly lower dosages (> 60\%). From an economic standpoint, this is a benefit of using $L$. gracilis EO, since use of minimal volumes of EO provides robust mycelial inhibition, which results in the economically efficient and effective control of pathogens.

The rapid degradation of EOs in the environment ( $\mathrm{Hu}$ and Coats, 2008) and its low degree of risk to the health of producers and final consumers are key benefits of using $L$. gracilis EOs as alternatives to conventional fungicides in the control phytopathogens. In in vivo conditions, the EO could be integrated with other pre and post-harvesting techniques, reducing environmental impacts associated with the exclusive use of synthetic agrochemicals.

Despite the promising findings of this study, we recommend that future studies take place, which assess the capacity of the EO to control phytopathogens in vivo, since the effects of the EO may differ from those observed under in vitro conditions. It is essential to evaluate the activity of the $L$. gracilis EO on plant species of commercial value and also establish safe concentrations of the product.

\section{Materials and Methods}

\section{Location of experiments and origins of materials}

The study was conducted at the Center for Agrifood Science and Technology (CCTA) of the Federal University of Campina Grande (UFCG), Campus of Pombal. The experiment was carried out in the Phytopathology laboratory of this institution, from February to March of 2018.

The phytopathogenic fungi collection was provided by Prof. Maria Menezes (Federal Rural University of PernambucoUFRPE), which contained strains used for in vitro experiments including C. gloeosporioides 3331, C. musae 3499, C. fructicola 3811 , C. asianum 3772 , A. alternata 0878 , A. brassicicola 0036, F. oxysporum f. sp. cubense 2141, F. solani 3826 and L. theobromae 4534. The fungi were preserved in sterile distilled water by the Castellani method for further use (Castellani, 1967).

L. gracilis EO was obtained using the steam distillation technique, which was carried out in the Laboratory of Biology II of the Department of Biology of State University of Rio Grande do Norte (UERN), Campus of Mossoró-RN.

\section{Treatments and experimental design}

Experiments had two sources of variation, eight treatments (five oil concentrations, one negative control, two positive 
controls) and nine fungal species. Experiments were performed using a completely randomized $8 \times 9$ factorial design, with five replicates each. The treatments included pure $L$. gracilis EO at concentrations of $0.0125,0.025,0.05$, 0.1 , and $0.2 \%$; a negative control (culture medium without supplementation); and two positive controls (culture medium supplemented with Tiram and Mancozeb commercial fungicides at concentrations recommended by their manufacturers of $1 \mathrm{~mL} \mathrm{~L}^{-1}$ and $0.2 \mathrm{~g} \mathrm{~L}^{-1}$, respectively). The concentrations used were selected based on work by Ugulino et al. (2018), that reported use of the oil between 0.4 to $1.0 \%$. To obtain the final concentrations, we used the direct dilution procedure in a culture medium (Pereira et al., 2006).

\section{Experimental procedures}

Different treatments were incorporated into autoclaved and molten potato dextrose agar media. After cooling, the media was poured into Petri dishes $9 \mathrm{~cm}$ in diameter under aseptic conditions. After solidification, culture medium disks, $1 \mathrm{~cm}$ in diameter, containing mycelia of each fungal species were transferred to the center of each treatment-containing plate. The plates were then wrapped in plastic film and stored in a biochemical oxygen demand incubator at $27 \pm 2^{\circ} \mathrm{C}$.

We measured the growth of each colony daily one filled the entire surface of the culture medium for a maximum period of $7 \mathrm{~d}$. The daily measurements consisted of the average of two perpendicular diameters, which were obtained with the aid of a graduated ruler. The mean diameters facilitated the calculation of percentage of mycelial growth inhibition (PGI; Bastos, 1997) was calculated according to formula (1) as follows:

$P G I=\frac{[\text { (negative control growth-treatment growth })] \times 100}{\text { negative control growth }}$,

(1)

And the and index of mycelial growth speed (IMGS; Oliveira, 1991) was calculated according to equation (2) as follows:

$I M G S=\sum \frac{\text { current mycelial growth-previous mycelial growth }}{\text { number of days of incubation }}$. (2)

\section{Statistical analysis}

The effects of fungal species, oil concentrations, and interactions between these two variables on PGI and IMGS values were evaluated using a two-way PERMANOVA (ANOVA with 9,999 permutations). We used this nonparametric statistic due to the absence of variance associated with some treatments. Regressions were performed using quadratic plateau models to verify the effects of oil concentrations on fungal growth.

To evaluate differences between oil and fungicide (positive control) treatments, we applied Mann-Whitney pairwise comparisons. All differences with a probability value below $5 \%$ were considered significant. The analyses were performed using R 3.5.1 software (R Core Team, 2019) and the Past 3.12 program (Hammer et al., 2001).

\section{Conclusion}

Under in vitro conditions, L. gracilis (Schauer) EO completely inhibited mycelial growth of the fungal species $C$. gloeosporioides, C. musae, C. fructicola, C. asianum, A. alternata, A. brassicicola, F. oxysporum f. sp. cubense, $F$. solani, and $L$. theobromae when provided at concentrations of 0.0125 to $0.1 \%$. The effect of the oil was similar or superior to synthetic fungicides Tiram and Mancozeb.

\section{Acknowledgments}

We thank the Coordination for the Improvement of Higher Education Personnel (CAPES) for granting a scholarship to the first author.

\section{References}

Abbaszadeh S, Sharifzadeh A, Shokri H, Khosravi AR, Abbaszadeh A (2014) Antifungal efficacy of thymol, carvacrol, eugenol and menthol as alternative agents to control the growth of food-relevant fungi. J Mycol Med. 24(2):1-6.

Abdel-Kader MM, El-Mougy NS, Lashin SM (2011). Essential oils and Trichoderma harzianum as an integrated control measure against faba bean root rot pathogens. J Plant Prot Res. 51(3): 306-311.

Adami ACO, Sousa EP, Fricks LB, Miranda SHG (2016). Oferta de exportação de frutas do Brasil: $O$ caso da manga e do melão, no período de 2004 a 2015. Rev Econ Nordeste. 47(4): 63-78.

Ahmad A, Khan A, Akhtar F, Yousuf S, Xess I, Khan LA, Manzoor N (2011). Fungicidal activity of thymol and carvacrol by disrupting ergosterol biosynthesis and membrane integrity against Candida. Eur J Clin Microbiol. 30(1): 41-50.

Albuquerque CC, Camara TR, Mariano RLR, Willadino L, Júnior CM, Ulisses C (2006). Antimicrobial action of the essential oil of Lippia gracilis Schauer. Braz Arch Biol Techn. 49(4): 527-535.

Antunes MDC, Cavaco AM (2010). The use of essential oils for postharvest decay control. A review. Flavour Fragr J. 25: 351-366.

Aoki T, O’Donnell K, Homma Y, Lattanzi AR (2003). Suddendeath syndrome of soybean is caused by two morphologically and phylogenetically distinct species within the Fusarium solani species complex - $F$. virguliforme in North America and F. tucumaniae in South America. Mycologia. 95(4): 660-684.

Bagamboula CF, Uyttendaele M, Debevere J (2004). Inhibitory effect of thyme and basil essential oils, carvacrol, thymol, estragol, linalool and p-cymene towards Shigella sonnei and S. flexneri. Food Microbiol. 21: 33-42.

Barboza HS (2015). Efeito fungitóxico do óleo essencial de alecrim-da-chapada em Alternaria sp. 2015. 31fls. Trabalho de Conclusão de Curso (Graduação em Agronomia) Universidade Federal do Semi-Árido, Mossoró, RN, Brasil.

Bastos CN (1997). Efeito do óleo de Piper aduncum sobre Crinipelis perniciosa e outros fungos fitopatogênicos. Fitopatol Bras. 22(3): 441-443.

Bebber DP, Gurr SJ (2015). Crop-destroying fungal and oomycete pathogens challenge food security. Fungal Genet Biol. 74: 62-64.

Bitu VC, Fecundo HD, Costa JG, Coutinho HD, Rodrigues FF, Santana NM, Botelho MA, Menezes IR (2014). Chemical composition of the essential oil of Lippia gracilis Schauer 
leaves and its potential as modulator of bacterial resistance. Nat Prod Res. 28(6): 399-402.

Bonnet LP, Hurmann ES, Júnior MCP, Rosa TB, Soares LS (2013). Biocontrole in vitro de Colletotrichum musae por Isolados de Trichoderma spp. Uniciências. 17(1): 5-10.

Brum RBCS, Castro HG, Cardon CH, Pererira AS, Cardoso DP, Santos GR (2014). Atividade antifúngica de óleos essenciais sobre fungos fitopatogênicos. Magistra. 26(3): 361-371.

Candido e Silva EK, Melo LGL (2013). Manejo de doenças de plantas: Um enfoque agroecológico. Revista EDUCAmazônia - Educação Sociedade e Meio Ambiente. 10(1): 143-157.

Carnelossi PR, Schwan-Estrada KRF, Cruz MES, Itako AT, Mesquini RM (2009). Óleos essenciais no controle póscolheita de Colletotrichum gloeosporioides em mamão. Rev Bras Plantas Med. 11(4): 399-406.

Castellani A (1967). Maintenance and cultivation of common pathogenic fungi of man in sterile distilled water. Further Researches. J Trop Med Hyg. 70: 181-184.

Castro NR, Coêlho RSB, Laranjeira D, Couto EF, Souza MBR (2008). Ocorrência, métodos de inoculação e agressividade de Fusarium oxysporum f. sp. cubense em Heliconia spp. Summa Phytopathol. 34(2): 127-130.

Coimbra JL, Soares ACF, Garrido MS, Sousa CS, Ribeiro FLB (2006). Toxicidade de extratos vegetais a Scutellonema bradys. Pesq Agropecu Bras. 41(7): 1209-1211.

Cruz EMO, Costa-Júnior LM, Pinto AO, Santos DA, Araújo SA, Arrogani-Blank MF, Bacci, L, Alvez PB, Cavalcanti SCH, Blank AF (2013). Acaricidal activity of Lippia gracilis essential oil and its major constituents on the tick Rhipicephalus (Boophilus) microplus. Vet Parasitol. 195(1-2): 198-202.

Deep S, Sharma P (2012). Host age as predisposing factor for incidence of black leaf spot of cauliflower caused by Alternaria brassicae and Alternaria brassicicola. Indian Phytopathol. 65(1): 71-75.

Feng W, Zheng X (2007). Essential oils to control Alternaria alternata in vitro and in vivo. Food Control. 18: 1126-1130.

Ferraz RPC, Bomfim DS, Carvalho NC, Soares MB, Silva TB, Machado WJ, Prata AP, Costa EV, Moraes VR, Nogueira PC, Bezerra DP (2013). Cytotoxic effect of leaf essential oil of Lippia gracilis Schauer (Verbenaceae). Phytomedicine. 20(7): 615-621.

França KRS, Silva TL, Cardoso TAL, Ugulino ALN, Rodrigues APM, Mendonça Júnior AF (2018). In vitro effect of essential oil of peppermint (Mentha $\mathrm{x}$ piperita L.) on the mycelial growth of Alternaria alternata. J Exp Agric Int. 26(5): 1-7.

Franco CS, Ribeiro AF, Carvalho NCC, Monteiro OS, Silva JKR, Andrade EHA, Maia JGS (2014). Composition and antioxidant and antifungal activities of the essential oil from Lippia gracilis Schauer. Afr J Biotechnol. 13(30): 31073113.

Freire MM, Jham GN, Dhingra OD, Jardim CM, Barcelos RC, Valente V.M (2012). Composition, antifungal activity and main fungitoxic components of the essential oil of Mentha piperita L. J Food Safety. 32(1): 29-36.

Guilhon CC, Raymundo LJ, Alviano DS, Blank AF, ArrigoniBlank MF, Matheus ME, Cavalcanti SC, Alviano CS, Fernandes PD (2011). Characterization of the antiinflammatory and antinociceptive activities and the mechanism of the action of Lippia gracilis essential oil. J Ethnopharmacol. 135: 406-413.

Hammer O, Harper DAT, Ryan PD (2001). Past:
Paleontological statistics software package for education and data analysis. Paleontol Electronica, 4(1): 9.

Hoyos JMA, Alves E, Rozwalka LC, Souza EA, Zeviani WM (2012). Antifungal activity and ultrastructural alterations in Pseudocercospora griseola treated with essential oils. Ciênc Agrotec. 36(3): 270-284.

Hu D, Coats J (2008). Evaluation of the environmental fate of thymol and phenethyl propionate in the laboratory. Pest Manag Sci, 64: 775-779.

Isman MB, Machial CM (2006). Pesticides based on plant essential oils: From traditional practice to commercialization. In: Rai, M., \& Caepinella, M.C. Advances in Phytomedicine: Naturally Occurring Bioactive Compounds, 3: 29-44.

Jardim CM, Jham GN, Dhingra OD, Freire MM (2010). Chemical composition and antifungal activity of the hexane extract of the Brazilian Chenopodium Ambrosioides L. J Braz Chem Soc. 21(10): 1814-1818.

Kordali S, Cakir A, Ozer H, Cakmakci R, Kesdek M, Mete E (2008). Antifungal, phytotoxic and insecticidal properties of essential oil isolated from Turkish Origanum acutidens and its three components, carvacrol, thymol and pcymene. Bioresource Technol. 99(18): 8788-8795.

Matos FJDA, Machado MIL, Craveiro AA, Alencar JW, Silva MGV (1999). Medicinal plants of northeast brazil containing thymol and carvacrol - Lippia sidoides cham. and L. gracilis H.B.K. (Verbenaceae). J Essent Oil Res. 11(6): 666-668.

Mishra AK, Dubey NK (1994). Evaluation of some essential oils for their toxicity against fungi causing deterioration of stored food commodities. Appl Environ Microbiol. 60(40): 1101-1105.

Morcia C, Malnati M, Terzi V (2012). In vitro antifungal activity of terpinen-4-ol, eugenol, carvone, 1, 8-cineole (eucalyptol) and thymol against mycotoxigenic plant pathogens. Food Addit Contam. 29(3): 415-422.

Mota JCO, Pessoa MNG, Viana FMP, Neto MA (2002) Efeito de extratos e óleos essenciais de plantas medicinais no controle in vitro de Lasiodiplodia theobromae. Fitopatol Venez. 15(1): 2-6.

Muniz CR, Freire FCO, Viana FMP, Cardoso JE, Cooke P, Wood D, Guedes MIF (2011). Colonization of cashew plants by Lasiodiplodia theobromae: Microscopical features. Micron. 42: 419-428.

Nascimento FV, Santos MC, Valdebenito-Sanhueza RM, Bartnicki VA (2014). Hidrotermia e radiação UV-C no controle de patógenos de manga e melão. Summa Phytopathol. 40(4): 313-317.

Oliveira Júnior LFG, Santos RB, Reis FO, Matsumoto ST, Bispo WMS, Machado LP, Oliveira LFM (2013). Efeito fungitóxico do óleo essencial de aroeira da praia (Schinus terebinthifolius RADDI) sobre Colletotrichum gloeosporioides. Rev Bras Plantas Med. 15(1): 150-157.

Oliveira JA (1991). Efeito do tratamento fungicida em sementes no controle de tombamento de plântulas de pepino (Cucumis sativas L.) e pimentão (Capsicum annum L.). 1991. 111 f. Dissertação (Mestrado em Fitossanidade) Escola Superior de Agricultura de Lavras, Lavras, MG, Brasil.

Oliveira PDL, Oliveira KAR, Vieira WADS, Câmara MPS, Souza EL (2018). Control of anthracnose caused by Colletotrichum species in guava, mango and papaya using synergistic combinations of chitosan and Cymbopogon citratus (D.C. 
ex Nees) Stapf. essential oil. Int J Food Microbiol. 266: 8794.

Peixinho GS, Ribeiro VG, Amorin EPR (2017). Ação do óleo essencial de menta (Mentha arvensis) sobre o patógeno Lasiodiplodia theobromae em cachos de videira cv. Itália. Summa Phytopathol. 43(1): 32-35.

Pereira MC, Vilela GR, Costa LMAS, Silva RF, Fernandes AF, Fonseca EWN, Picolli RH. et al. (2006). Inibição do desenvolvimento fúngico através da utilização de óleos essenciais de condimentos. Ciênc Agrotec. 30(4): 731-738.

Perina FJ. (2014). Óleos essenciais e frações majoritárias ativas no controle da mancha marrom de alternaria (Alternaria alternata) em tangerina ponkan. 2014. 112f. Tese (Doutorado em Agronomia). Universidade Federal de Lavras, Lavras, MG, Brasil.

Pina-Vaz C, Gonçalves Rodrigues A, Pinto E, Oliveira SC, Tavares C, Salgueiro L, Cavaleiro C, Gonçalves MJ, Oliveira JM (2004). Antifungal activity of Thymus oils and their major compounds. J Eur Acad Dermatol Venereo. 18(1): 73-78.

Poltronieri LS, Trindade DR, Albuquerque FC, Duarte MR, Cardoso SS (2002). Incidência de Fusarium solani em mandioca no estado do Pará. Fitopatol Bras. 27(5): 544.

R Core Team. (2019). A language and environment for statistical computing. $\mathrm{R}$ Foundation for Statistical Computing, Vienna, Austria; Disponível em: https://www.R-project.org/.

Ribeiro JG, Serra IMRS, Araújo MUP (2016). Uso de produtos naturais no controle de antracnose causada por Colletotrichum gloeosporioides em mamão. Summa Phytopathol. 42(2): 160-164.

Russo M, Suraci F, Postorino S, Serra D, Roccotelli A, Agosteo GE (2013). Essential oil chemical composition and antifungal effects on Sclerotium cepivorum of Thymus capitatus wild populations from Calabria, southern Italy. Rev Bras Farmacogn. 23(2): 239-248.

Santos ACA, Rossato M, Serafini LA, Bueno M, Crippa LB, Sartori VC, Dellacassa E, Moyna P (2010). Efeito fungicida dos óleos essenciais de Schinus molle L. e Schinus terebinthifolius Raddi, Anacardiaceae, do Rio Grande do Sul. Rev Bras Farmacogn. 20(2): 154-159.

Santos ITBF, Santos TS, Silva FLS, Gagliardi PR, Oliveira LFG, Blank AF (2014). Óleo essencial de Schinus terebinthifolius
Raddi como controle alternativo de Colletothrichum gloeosporioides e Lasiodiplodia theobromae, fungos fitopatogênicos de pós-colheita. Revista GEINTEC. 4(4): 1409-1417.

Segvić Klarić M, Kosalec I, Mastelić J, Piecková E, Pepeljnak S (2007). Antifungal activity of thyme (Thymus vulgaris L.) essential oil and thymol against moulds from damp dwellings. Lett Appl Microbiol. 44: 36-42.

Shivas RG, Tan YP, Edwards J, Dinh Q, Maxwell A, Andjic V, Liberato JR, Anderson C, Beasley DR, Bransgrove K, Coates LM, Cowan K, Daniel R, Dean JR, Lomavatu MF, MercadoEscueta D, Mitchell RW, Thangavel R, Tran-Nguyen LTT, Weir BS (2016). Colletotrichum species in Australia. Australas Plant Path. 45(5): 447-464.

Silva VM, Costa-Carvalho RR, Fontes MG, Araújo ER, Pimenta-Neto AA, Blank AF, Laranjeira D. (2012). Atividade antifúngica de Lippia sidoides e Lippia gracilis na inibição do crescimento de Rhizoctonia solani. In: $52^{\circ}$ Congresso Brasileiro de Olericultura, 2012, Salvador. Agroindustrialização de hortaliças: Geração de emprego e renda no campo, 30: 2135-2140.

Silva WJ, Dória GA, Nunes RS, Carvalho GA, Blank AF, Alves PB, Marçal MR, Cavalcanti SC (2008). Effects of essential oils on Aedes aegypti larvae: Alternatives to environmentally safe insecticides. Bioresource Technol. 99(8): 3251-3255.

Souza Júnior IT, Sales NLP, Martins ER (2009). Efeito fungitóxico de óleos essenciais sobre Colletotrichum gloeosporioides, isolado do maracujazeiro amarelo. Biotemas. 22(3): 77-83.

Teixeira H, Júnior JP, Vieira RF, Silva MB, Ferro CG, Lehner MS (2012). Trichoderma spp. decrease Fusarium root rot in common bean. Summa Phytopathol. 38(4): 334-336.

Udomsilp J, Piyo A, Khan-Khun P, Thobunluepop P (2009). Antifungal properties of essential oils from Thai medical plants against rice pathogenic fungi. As J Food Ag-Ind. Special Issue: 24-30.

Ugulino ALN, Mendonça Júnior AF, Rodrigues APMS, Santos $A B$, França KRSF, Cardoso TAL, Prado Júnior LS (2018). Inhibition effect of vegetable oils on the mycelial growth of Macrophomina phaseolina (Tassi.). Goid. J Agr Sci. 10(6): 49-56. 